\title{
КОНТРОЛЬ СТАНУ КРОВІ ТА ЯКОСТІ СПЕРМИ КНУРІВ-ПЛІДНИКІВ РІЗНИХ ГЕНОТИПІВ I ЕФЕКТИВНІСТЬ ВІДТВОРЕННЯ СТАДА
}

\author{
Зєльдін Валерій Феліксович \\ кандидат сільськогосподарських наук \\ ДУ Інститут зернових культур НААН \\ ORCID: 0000-0002-5708-3105 \\ Email: izkzoo3337@gmail.com
}

Козир Володимир Семенович доктор сільськогосподарських наук, академік НААН України ДУ Інститут зернових культур НААН ORCID: 0000-0002-0275-475x Email: izkzoo3337@gmail.com

Сокрут Олександр Володимирович кандидат сільськогосподарських наук ДУ Інститут зернових культур НААН ORCID: 0000-0002-9541-5713 Email: izkzoo3337@gmail.com

Досліджено біохімічний склад крові та сперми кнурів-плідників племпідприємств великої білої породи, української м'ясної, харківської та дніпропетровської селекції. Встановлень, що середні біохімічні показники крові і сперми кнурів не виходили за межі біологічної норми. Середня кількість сперматозоїдів у відфрільтрованому еякуляті кнурів дослідних ге-

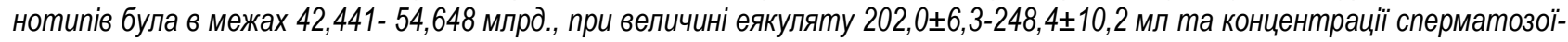

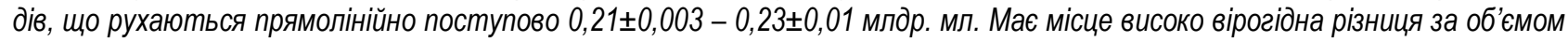
відфрільтрованого еякуляту між плідником української м'ясної породи дніпропетровської та харківської селекцій на користь першої. Коефріцієнт кореляції між Рh сперми кнурів дослідних генотипів і концентрацією сперматозоїдів в 1 см склав -0,323 (велика біла порода) - 0,294 (українська м'ясна порода харківської селекції), - 0,208 (українська м'ясна порода дніпропетровської селекції). Рівень репрезентабельності величин розрахованих коефіцієнтів кореляції між ознаками був в межах P>0,05- $P<0,05$. Середня кількість одержаних спермо доз з одного еякуляту становила 8,5 доз (м'ясна порода харківської селекиії) та 10,9 дози українська м'ясна порода дніпропетровської селекиії) при величині показника 10,0 доз у кнурів великої білої породи. Запліднюваність маточного поголів'я від першого осіменіння в залежності від методу розве-

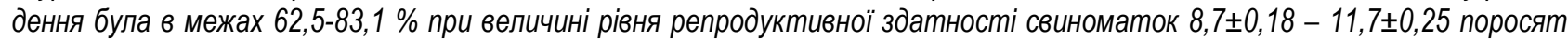
на один опорос, що в цілому характеризує якість маточного поголів'я в здатності до запліднення за один статевий цикл та рівня племінної роботи в стаді у напрямку вдосконалення ознаки з низьким ступенем ії успадкування.

Ключові слова: генотип, кров, сперма, кнур-плідник, ефекттивність відтворення

DOI: https://doi.org/10.32845/bsnau.lvst.2020.4.6

Скорочення терміну переносу селекційних досягнень з племінного сектору в товарний можливо за рахунок методу штучного осіменіння. В умовах нестабільної економіки для галузі тваринництва особливо актуальним $є$ питання раціонального та ефективного використання плідників. Контроль за станом біохімічного складу крові, показників якості сперми кнурів дає можливість технологам галузі, за стандартного режиму використання і відповідних зоотехнічних умовах годівлі та утримання кнурів, об'єктивно оцінити фізіологічний стан плідника. В той же час показники якості сперми не $є$ предметом масової селекції в маточних стадах у господарствах вищої племінної категорії, які постачають на племпідприємства та парувальну мережу ремонтних кнурців. В наслідок цього технологам племпідприємств складно прогнозувати якість майбутньої спермопродукції у плідників першого року використання, що віддають сперму мануальним способом або на штучну вагіну. Тому дана актуальна проблема і обумовила напрямок наших досліджень.

Матеріали та методи досліджень. Матеріалом для досліджень були біологічні середовища: кров та сперма плідників великої білої та української м'ясної породи. Годів-

ля та утримання тварин була згідно вимог [5]. Біохімічний склад сперми та крові кнурів різних генотипів був досліджений на кафедрі біохімії, медичної та фрармацевтичної хімії Дніпропетровської державної медичної академії.

Оцінка якості сперми плідників була проведена за такими показниками: об'єм відфільтрованого еякуляту, мл; концентрація сперматозоїдів в 1 мл, млрд.; активність сперматозоїдів, бал; абсолютний показник здатності сперматозоїдів до виживання, один. вим., що відповідає вимогам «Инструкции по организации и технологии работы станций и предприятий по искусственному осеменению сельскохозяйственных животных, МСХ СССР, 1981», розбавлення сперми проводилося стандартним розріджувачем - ГХЦС (ГОСТ 17637-72) [5].

Показники крові кнурів вивчали за показниками: вміст гемоглобіну - за методикою Г.В.Дервіз, А.І. Воробйова (1959), кількість еритроцитів - при умовах описаних A.І. Воробйовим, 1959; лейкоцити - в камері із сіткою Горяєва, використовуючи розчин Тюрка; лейкоцитарна формула мазки крові забарвлювали барвником Романовського-Гамза, за загальноприйнятою методикою (В.І. Зайцев, А.В. Сілаєв 
та ін., 1958); цукор в крові - метод Самоджі; вміст глюкози метод Хультмана; загальний білок - методом рефрактометрії; резервна лужність - за методом Ван-Слайка; кальцій за методом де Ваарда; фоссрор неорганічний - за методом Р.Я.Юделевича, в модифікації Коромислова.

Були вивчені такі показники сперми кнурів: калій та натрій - методом полум'яної фотометрії; хлор - методом меркуріметричного титрування; фосфор неорганічний методом відновлення фосфорно-молібденової кислоти; загальний білок - біуретовий метод; щільність - ареометром; кислотність - іономіром; кальцій - за методом де Ваарда; глюкоза фрруктоза -методом Хультмана.

Вивчено відтворювальну і репродуктивну здатність свиней за такими показниками: запліднююча здатність сперми - кількість запліднених свиноматок від первинного осіменіння, \%; багатоплідність - кількість життєздатних поросят, одержаних на 1 опорос від свиноматки, гол.; молочність - маса гнізда в 21 день, кг; маса гнізда при відлученні загальна маса усіх поросят у гнізді на день відлучення, кг. Отриманий експериментальний матеріал дослідження оброблено статистично.
Результати досліджень. До числа найбільш характерних показників якості спермопродукції віднесено: число сперматозоїдів в еякуляті, об'єм відфільтрованого еякуляту, концентрація сперми в 1 мл, активність та здатність сперматозоїдів до виживання. Кількісні і якісні показники еякулятів плідників дослідних генотипів наведені в таблиці 1.

Встановлено, що найбільший об'єм еякуляту був одержаний від кнурів української м'ясної породи Дніпропетровської селекції, найменший - у плідників української м'ясної породи Харківської селекції. Різниця склала $46,4 \pm 11,99$ мл (P<0,001). Плідники великої білої породи за цією ознакою займають проміжне положення при невірогідній різниці в різних варіантах порівнянь. За концентрацією сперматозоїдів суттєвих відмінностей між кнурами різних генотипів не виявлено.

Найнижчою активністю сперматозоїдів характеризуються кнури української м'ясної породи Дніпропетровської селекції. Вони вірогідно уступають плідникам великої білої породи $(8,5 \pm 0,14, \mathrm{P}<0,01)$ і української м'ясної породи Харківської селекції $(8,5 \pm 0,17, \mathrm{P}<0,01)$.

Таблиця 1

Якість спермопродукції кнурів великої білої породи, української м'ясної Харківської і Дніпропетровської селекції

$$
\bar{X} \pm S_{x}
$$

\begin{tabular}{|c|c|c|c|c|c|c|c|c|c|}
\hline \multirow[b]{2}{*}{ Генотип } & \multirow[b]{2}{*}{ Група } & \multirow[b]{2}{*}{$\mathrm{n}$} & \multirow{2}{*}{$\begin{array}{c}\text { Одержано еякулятів } \\
\text { за перший рік } \\
\text { використання, шт. }\end{array}$} & \multicolumn{6}{|c|}{ Показники якості спермопродукції } \\
\hline & & & & $\begin{array}{l}\text { Об'єм відфільт. } \\
\text { еякул., мл }\end{array}$ & Cv, \% & $\begin{array}{c}\text { Конц. сперм, } \\
\text { млрд/мл }\end{array}$ & $\mathrm{Cv}, \%$ & Активн., бал & $\mathrm{Cv}, \%$ \\
\hline BE & 1 & 13 & 553 & $217,8 \pm 12,4$ & 20,5 & $0,23 \pm 0,01$ & 17,6 & $8,5 \pm 0,14$ & 6,1 \\
\hline $\mathrm{YM} \times \mathrm{xc}$ & 2 & 10 & 507 & $202,0 \pm 6,3$ & 9,9 & $0,21 \pm 0,03$ & 5,3 & $8,5 \pm 0,17$ & 6,2 \\
\hline УМдс & 3 & 14 & 826 & $248,4 \pm 10,2$ & 16,9 & $0,22 \pm 0,06$ & 10,7 & $7,7 \pm 0,17$ & 6,9 \\
\hline
\end{tabular}

Була встановлена вірогідність різниці середніх показників якості спермопродукції плідників першого року використання: об'єм відфільтрованого еякуляту, мл - між ІІІ групою (УМдс) i II (УМхс) при $t d=3,862$ при $\mathrm{P}<0,001$. В усіх інших випадках порівняння якості спермопродукції кнурів дослідних генотипів різниця між «середніми» була не вірогідна $(\mathrm{P}<0,05)$; концентрація сперматозоїдів в 1 мл нативної сперми, млрд./мл - вірогідної різниці між «середніми» не встановлено ( $\mathrm{P}>0,05)$; активність сперматозоїдів, бал вірогідна різниця середніх значень показника відмічена в двох випадках, при порівнянні показників I гр. (ВБ) і III груп
(УМхс-УМдс), а також II i III груп, при $\mathrm{td}=3,633$ i td=3,328 відповідно, що відповідає другому рівню вірогідності $(P<0,01)$.

Визначаючи технолого-економічні якості спермопродукції у дослідних генотипів кнурів, ми встановили, що плідники генотипів великої білої і кнури української м'ясної породи Дніпропетровської селекції виробляють свою специфрічну продукцію в умовах племпідприємств при більш вигідних для племпідприємств показниках. Технологічні якості спермопродукції кнурів різних генотипів першого року використання наведені в таблиці 2.

Технологічні показники якості спермопродукції кнурів різних генотипів

Таблиця 2 першого року використання

\begin{tabular}{|c|c|c|c|c|c|}
\hline Генотип & $\mathrm{n}$ & $\begin{array}{c}\text { Одержано еякулятів, } \\
\text { шт. }\end{array}$ & $\begin{array}{c}\text { Середня кількість сперматозоїдів в } \\
\text { 1еякуляті, млрд. }\end{array}$ & $\begin{array}{c}\text { Середня кількість одержаних спермодоз з } \\
\text { 1 еякуляту (5 млрд. в дозі) }\end{array}$ & \% від контролю \\
\hline ВБ & 13 & 553 & 50,094 & 10,0 & 100 \\
\hline УМхс & 10 & 507 & 42,441 & 8,5 & 85 \\
\hline УМдс & 14 & 826 & 54,648 & 10,9 & 109 \\
\hline
\end{tabular}

Аналіз даних таблиці свідчить про високий технологічний рівень якості спермопродукції тварин комбінованого рівня продуктивності (велика біла), а також тварин української м'ясної породи Дніпропетровської селекції, які за рівнем м'ясної продуктивності практично ідентичні генотипу великої білої. Українська м'ясна порода Харківської селекції в наших дослідах має відносно гірші показники технологічної цінності якості спермопродукції, ніж тварини великої білої і української м'ясної породи Дніпропетровської селекції.

3 кожного відфільтрованого еякуляту кнурів української м'ясної породи Дніпропетровської селекції було одер- жано на 0,9 спермодози більше, ніж від плідників великої білої породи і на 2,4, ніж у плідників української м'ясної Харківської селекції. В свою чергу це дозволяє додатково осіменити протягом року, при отриманні від повновікового плідника не менше 120 еякулятів щорічно від 54 до 144 свиноматок, витрачаючи на осіменіння однієї матки за один статевий цикл, 2 спермодози.

Морфологічні показники крові значною мірою відображають фізіологічний стан тварин і характер обмінних процесів, що відбуваються в організмі. У кнурів-плідників, в порівнянні з плідниками інших видів сільськогосподарських 
тварин на утворення сперми витрачається найбільша кількість енергії і поживних речовин, тому незбалансованість раціону годівлі різко впливає на якість спермопродукції і стан здоров'я тварини. Гематологічні і біохімічні показники крові свиней великої білої породи, української м'ясної поро- ди Харківської селекції і Дніпропетровської селекції визначали на кафедрі біохімії, медичної та фармацевтичної хімії Дніпропетровської державної медичної академії. Результати досліджень наведені в таблиці 3.

Загальні гематологічні і біохімічні показники крові свиней дослідних генотипів - великої білої, української м'ясної породи Харківської і Дніпропетровської селекції, $\bar{X} \pm S_{x}$

\begin{tabular}{|l|c|c|c|}
\hline \multicolumn{1}{|c|}{ Показники } & BБ & УМxс & уМ \\
\hline \multicolumn{1}{|c|}{ Гемоглобін, г/л } & $100 \pm 1,58$ & $101,25 \pm 1,08$ & $99 \pm 1,87$ \\
\hline Еритроцити, млн/мм & $5,58 \pm 0,06$ & $5,76 \pm 0,023$ & $5,53 \pm 0,05$ \\
\hline Лейкоцити, \%і & $16,54 \pm 0,41$ & $15,22 \pm 0,18$ & $16,0 \pm 0,32$ \\
\hline Загальний білок, г\% & $7,79 \pm 0,13$ & $7,88 \pm 0,11$ & $7,78 \pm 0,1$ \\
\hline Цукор, мг\% $\%$ & $66,93 \pm 0,59$ & $66,15 \pm 0,52$ & $66,6 \pm 0,53$ \\
\hline Глюкоза, мг\% & $60,66 \pm 0,39$ & $60,75 \pm 0,28$ & $60,66 \pm 0,27$ \\
\hline Резервна лужність, мг/л & $2890 \pm 51,0$ & $2962,52 \pm 23,9$ & $2920 \pm 40,62$ \\
\hline Кальцій, мг/\% & $11,82 \pm 0,51$ & $11,75 \pm 0,388$ & $11,14 \pm 0,22$ \\
\hline Фосфор неорганічний, мг\% & $11,22 \pm 0,1$ & $11,23 \pm 0,09$ & $11,1 \pm 0,04$ \\
\hline Лізоцимна активність сироватки крові (до паратифної культури), \% & $40,1 \pm 0,14$ & $40,3 \pm 0,11$ & $40,0 \pm 0,26$ \\
\hline Бактерицидна активність сироватки крові (до паратифної культури), \% & $40,15 \pm 0,07$ & $40,4 \pm 0,06$ & $40,1 \pm 0,04$ \\
\hline
\end{tabular}

Показники крові кнурів досліджуваних генотипів засвідчили, що тварини були клінічно здорові, а середній рівень наведених показників крові відповідав нормі. Для вивчення фізико-хімічного складу сперми кнурів-плідників дослідних генотипів великої білої породи, української м'ясної породи Харківського селекції і кнурів української м'ясної породи Дніпропетровської селекції, які формують систему розведення свиней Дніпропетровської області, були використанні повновікові плідники Томаківської філії Солонянського племпідприємства.

Кнури-плідники, сперма яких була досліджена за фрізико-хімічними властивостями, були типові для своїх порід, клінічно-здорові за сумарним бонітувальним класом відповідали вимогам класу еліта. Сперму від кнурів в умовах плем- підприємств, брали згідно встановленого графіка. Плідники отримували стандартний раціон годівлі за структурою, згідно вимог [5].

Сперму для досліджень брали вранці, відфільтровували, розбавляли синтетичним середовищем ГХЦС, згідно «ГОСТ 17637-72». Розбавлену сперму при використанні термоса-ящика (боксу) автотранспортом доставляли в лабораторію кафедри біохімії ДМА).

Кількісні показники спермопродукції кнурів дослідних генотипів (об'єм відфільтрованого еякуляту (мл), концентрація сперміїв) в 1 мл (млрд./мл), активність сперміїв враховувалися по місцю взяття сперми. Облік якості показників спермопродукції кнурів проводили на племпідприємстві.

Таблиця 4

Фізико-хімічний склад сперми кнурів дослідних генотипів, $\bar{X} \pm S_{x}$

\begin{tabular}{|l|c|c|c|}
\hline \multicolumn{1}{|c|}{ Показники } & ВБ & УМхс & \multicolumn{1}{c|}{ УМ } \\
\hline Щільність, г/мл & $1,0226 \pm 0,00093$ & $1,0226 \pm 0,00181$ & $1,02 \pm 0,0007$ \\
\hline рН & $7,626 \pm 0,0271$ & $7,624 \pm 0,0081$ & $3,446 \pm 0,0254$ \\
\hline Загальний білок, г/л & $41,64 \pm 0,566$ & $41,04 \pm 0,385$ & $1,648 \pm 0,0637$ \\
\hline Сечовина, мг/... & $1,61 \pm 0,122$ & $2,558 \pm 0,0381$ & $0,59 \pm 0,007$ \\
\hline Фосфрор неорганічний, ммоль/л & $0,634 \pm 0,0040$ & $0,616 \pm 0,0110$ & $140,6 \pm 0,69$ \\
\hline Натрій, ммоль/л & $138,5 \pm 0,87$ & $135,82 \pm 1,290$ & $25,3 \pm 0,43$ \\
\hline Калій, ммоль/л & $23,5 \pm 0,195$ & $20,2 \pm 0,126$ & $98,1 \pm 1,22$ \\
\hline Хлор, ммоль/л & $96,14 \pm 0,163$ & $93,52 \pm 0,546$ & $40,6 \pm 0,35$ \\
\hline Кальцій, ммоль/л & $41,56 \pm 0,216$ & $42,32 \pm 0,183$ & $1,01 \pm 0,028$ \\
\hline Глюкоза, мл/..... & $1,0 \pm 0,045$ & $0,946 \pm 0,0420$ & $11,88 \pm 0,058$ \\
\hline Фруктоза, мг/.... & $11,96 \pm 0,051$ & $11,98 \pm 0,073$ & $671,2 \pm 1,39$ \\
\hline Інозіт, мг/..... & $673,2 \pm 1,62$ & $672,0 \pm 1,05$ & \\
\hline
\end{tabular}

Нами були встановлені вірогідні відмінності у кнурів досліджуваних генотипів між окремими біохімічними показниками складу їх сперми. Так, величина рН, вміст білка і калію в спермі кнурів великої білої породи було вірогідно вищим, ніж у плідників кнури української м'ясної породи Дніпропетровської селекції (P<0,01). Відмінностей аналогічного характеру у плідників великої білої і української м'ясної породи Харківської селекції не спостерігалося. Відсутній також чинник системності відмінностей по всіх встановлених розбіжностях між плідниками української м'ясної Харківського типу i, порівняно з показниками якості сперми кнурів ве- ликої білої породи.

Дослідами C.I. Сердюка [18] встановлено, що між рН, свіжо отриманої сперми та концентрацією сперматозоїдів існує зворотній зв'язок: чим нижче рН, тим вище концентрація сперматозоїдів і навпаки. За його даними коефіцієнт кореляції між цими ознаками дорівнюють -0,33 $\pm 0,023$ при $\mathrm{td}=14,3$. В наших дослідах з вивчення рівня зв'язку між рН i концентрацією сперматозоїдів у кнурців досліджуваних генотипів було встановлено, що в великій білій породі (n=5) рівень зв'язку між вище наведеними показниками становив $r=-0,323$ при $\mathrm{P}<0,05$, в українській м'ясній породі Харківсько- 
го типу $r=-0,294$ при $\mathrm{P}<0,05$ у кнурів української м'ясної породи Дніпропетровської селекції $r=-0,208$ ( $P<0,05)$. Також має місце тенденція зниження коефіцієнта кореляції між рН і концентрацією сперматозоїдів, при зменшенні самого рH.
Рівень зв'язку між рН сперми і концентрацією сперматозоїдів в 1 мл сперми кнурів дослідних генотипів наведений в таблиці 5 .

Рівень зв'язку між рН сперми і концентрацією сперматозоїдів

Таблиця 5 в 1 мл сперми кнурів дослідних генотипів

\begin{tabular}{|c|c|c|c|c|}
\hline \multirow{2}{*}{ Показник } & \multirow{2}{*}{$\mathrm{n}$} & $\mathrm{B}$ & Генотип кнура & УМхс \\
\cline { 3 - 5 } & & 7,63 & 7,45 & 7,62 \\
\hline $\mathrm{pH}$ & 5 & 0,208 & 0,216 & 0,18 \\
\hline $\mathrm{K}$ & 5 & $-0,323$ & $-0,208$ & $-0,294$ \\
\hline $\mathrm{R}$ & 5 & $>0,05$ & $>0,05$ & $>0,05$ \\
\hline $\mathrm{P}$ & 5 & &
\end{tabular}

Таким чином, біохімічний аналіз сперми кнурів дослідних генотипів, віком 2 роки і більше показав деяку відмінність з різним ступенем вірогідності різниці «середніх». В той же час різниця «середніх» показників якості спермопродукції, з точки зору біохімічного складу її, не виходила за межі біологічної норми.

В.О. Медвєдєв та інші [18] вважали, що оцінка кнурів за запліднюючою здатністю буде об'єктивною і вірною в тому випадку, якщо вона проведена на стаді маток з загальною запліднюваністю не менш як $70 \%$.

Раціональне використання високоцінних плідників, створення короткотермінового запасу сперми і транспорту- вання її на великій відстані базується на можливості здатності до виживання сперматозоїдів поза організму плідника, при збереженні ії високої запліднювальної здатності. В наших дослідженнях ми встановили терміни здатності сперматозоїдів кнурів великої білої породи, української м'ясної Харківської селекції та української м'ясної породи Дніпропетровської селекції до виживання, при використанні стандартного розріджувача сперми (ГХЦС). Показники здатності сперматозоїдів кнурів великої білої, української м'ясної порід Харківської і Дніпропетровської селекції наведена в таблиці 6.

Таблиця 6

\section{Здатність сперматозоїдів кнурів великої білої, української м'ясної порід}

Харківської і Дніпропетровської селекції до виживання $\bar{X} \pm S_{x}$

\begin{tabular}{|c|c|c|c|c|c|c|c|}
\hline \multirow{2}{*}{$№$} & \multirow{2}{*}{ Генотип } & \multirow{2}{*}{ Кнурів } & \multicolumn{2}{|c|}{ в т.ч. } & \multicolumn{3}{|c|}{ Здатність сперматозоїдів до виживання } \\
\cline { 4 - 8 } & & & Комплексний модальний клас & решта & дослід & М $^{\circ}$ & Решта \\
\hline 1 & ВБ & 13 & 3 & 10 & $688,8 \pm 10,52$ & $730,0 \pm 3,61$ & $676,5 \pm 10,84$ \\
\hline 2 & УМхс & 10 & 4 & 6 & $642,6 \pm 17,0$ & $686,3 \pm 22,9$ & $613,5 \pm 15,3$ \\
\hline 3 & УМд & 14 & 4 & 10 & $667,3 \pm 14,2$ & $720,0 \pm 9,8$ & $646,3 \pm 14,8$ \\
\hline
\end{tabular}

Нами встановлена вірогідна різниця у здатності сперматозоїдів до виживання кнурів великої білої породи і української м'ясної породи Харківського типу при $t d=2,31$, що відповідає $\mathrm{P}<0,05$. В усіх інших випадках порівняння різниця цих показників була статистично невірогідна.

Дослідники багатьох країн все наполегливіше рекомендують відбирати самців за плодючістю та характером сперматогенезу, з урахуванням індивідуального розвитку тварин. Зазначимо, що прискіпливе і об'єктивне дослідження останнього показника створює передумови для досягнення високої запліднюваності тварин [4-8].

3 метою підвищення ефективності використання плідників дослідних генотипів у відтворенні стада, при використанні методу штучного осіменіння, в умовах дослідних господарств була вивчена здатність плідників великої білої породи, української м'ясної Харківського і Дніпропетровської селекції до ефективного запліднення свиноматок різного віку. Після попереднього вивчення маточного поголів'я в дослідних господарствах було відібрано поголів'я повновікових маток і ремонтних свинок парувального віку. Відібране поголів'я маток мало клас еліта та перший клас [6]. Умови годівлі і утримання піддослідних тварин відповідали зоогігієнічним вимогам. Початок охоти у свиноматок визначали за допомогою кнурів-пробників. Штучно осіменяли свиноматок двократно спермою нефракційним методом, за одну охоту. Після двократного осіменіння тварин протягом 3-х діб утри- мували в індивідуальних станках до згасання статевого рефрлексу. У кнурів, перед початком осіменіння свиноматок в дослідних господарствах визначили якість спермопродукції, яка відповідала мінімальним вимогам до якості спермопродукції, яка йде на осіменіння, згідно вимог [12]. Технологія проведення відтворення стада, 3 використанням методу штучного осіменіння відповідала вимогам. Результати запліднюючої здатності плідників дослідних генотипів при різних методах розведення наведено в таблиці 7. Штучно було осіменено маточне поголів'я в 5-ти дослідних господарствах, згідно графріків постачання сперми з племпідприємств та опорних пунктів зі штучного осіменіння. Метод природного парування свиней був використаний, як основний спосіб відтворення стада в репродукторах, де розводять такі генотипи свиней, як українська м'ясна порода Харківської селекції («Агро-Овен» Магдалинівського) і української м'ясної породи Дніпропетровської селекції («Перше Травня» Томаківського районів).

В ході дослідів, при відтворенні стада було використано 52 плідники і 633 голови маточного поголів'я, з яких 411 були повновікові свиноматки (64,9\% від усіх задіяних при відтворенні). Методом штучного осіменіння було покрито 435 свиноматок, в т.ч. 300 повновікових або (70,6\% від усіх задіяних при штучному осіменінні). Пройшло через опорос, в даному випадку - 317 свиноматок, в тому числі 238 повновікових свиноматок. 
Запліднююча здатність плідників дослідних генотипів при різних методах розведення, \%

\begin{tabular}{|c|c|c|c|c|c|c|c|c|c|c|c|c|c|c|c|c|}
\hline \multirow[b]{3}{*}{ 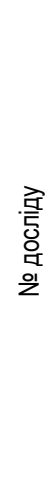 } & \multicolumn{2}{|c|}{$\begin{array}{c}\text { Метод } \\
\text { розведення }\end{array}$} & \multirow{3}{*}{ 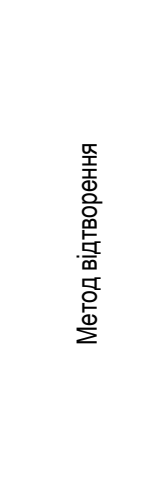 } & \multicolumn{4}{|c|}{ Дослідне поголів'я } & \multicolumn{3}{|c|}{$\begin{array}{c}\text { Опоросилося } \\
\text { свиноматок, гол. }\end{array}$} & \multicolumn{3}{|c|}{$\begin{array}{l}\text { Запліднюваність } \\
\text { свиноматок, \% }\end{array}$} & \multirow{3}{*}{ 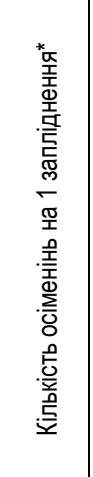 } & \multirow{3}{*}{ 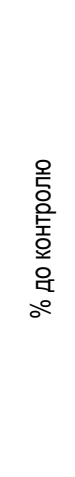 } & \multirow{3}{*}{ 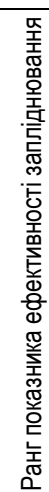 } \\
\hline & \multirow[b]{2}{*}{ 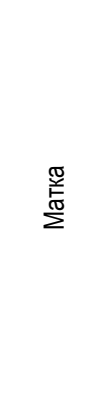 } & \multirow[b]{2}{*}{ 釜 } & & \multirow[b]{2}{*}{ 产 } & \multirow[b]{2}{*}{ 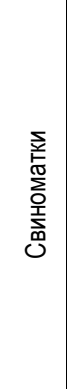 } & \multicolumn{2}{|c|}{ В т.ч. } & \multirow[b]{2}{*}{ 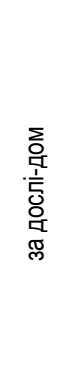 } & \multicolumn{2}{|c|}{ В Т.ч. } & \multirow[b]{2}{*}{ 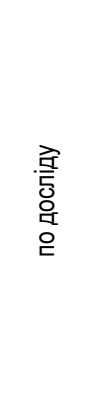 } & \multirow[b]{2}{*}{ 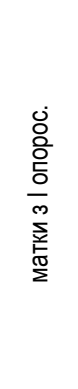 } & \multirow[b]{2}{*}{ 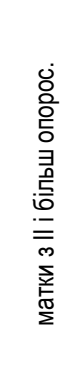 } & & & \\
\hline & & & & & & 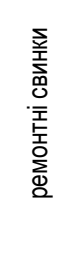 & 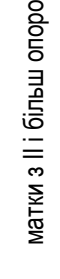 & & 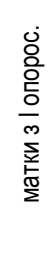 & 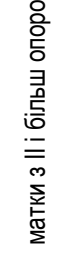 & & & & & & \\
\hline 1 & BE & BE & \begin{tabular}{l|} 
штучне \\
осіменіння
\end{tabular} & 13 & 99 & 38 & 61 & 70 & 25 & 45 & 70,7 & 65,8 & 73,8 & 3,172 & 100 & VI \\
\hline 2 & BE & $\mathrm{yM} \mathrm{xc}$ & $\begin{array}{l}\text { штучне } \\
\text { осіменіння }\end{array}$ & 10 & 102 & 17 & 86 & 80 & 6 & 74 & 76,9 & 35,3 & 87,1 & 2,924 & 92,2 & III \\
\hline 3 & BE & YMдс & $\begin{array}{l}\text { штучне } \\
\text { осіменіння }\end{array}$ & 9 & 67 & 18 & 49 & 52 & 11 & 41 & 77,6 & 61,1 & 83,6 & 2,896 & 91,3 & $\|$ \\
\hline 4 & $\mathrm{yM} \mathrm{xc}$ & $\mathrm{yMxc}$ & $\begin{array}{l}\text { природне } \\
\text { парування }\end{array}$ & 6 & 177 & 78 & 99 & 147 & 72 & 75 & 83,1 & 92,3 & 75,8 & 2,676 & 84,4 & 1 \\
\hline 5 & УМдс & YMAC & $\begin{array}{l}\text { природне } \\
\text { парування }\end{array}$ & 3 & 21 & 9 & 12 & 16 & 7 & 9 & 76,0 & 78,0 & 75,0 & 2,960 & 93,3 & IV \\
\hline 6 & $\mathrm{YM} \mathrm{Mc}_{\mathrm{x}}$ & $\mathrm{YM} \mathrm{MC}$ & $\begin{array}{l}\text { штучне } \\
\text { осіменіння }\end{array}$ & 6 & 98 & 26 & 72 & 72 & 13 & 59 & 73,5 & 50,0 & 81,9 & 3,060 & 96,5 & V \\
\hline 7 & $\mathrm{yM} \mathrm{xc}$ & BE & $\begin{array}{l}\text { штучне } \\
\text { осіменіння }\end{array}$ & 5 & 69 & 36 & 33 & 43 & 24 & 19 & 62,5 & 66,7 & 57,6 & 3,500 & 110 & VII \\
\hline
\end{tabular}

* прим $1 \%=0,04$

Заплідненість повновікових свиноматок була $79,9 \%$. В той же час, треба зазначити, що в групі ремонтних свинок цей показник склав лише $58,1 \%$. Це свідчить про відсутність цілеспрямованої селекції свиней за показником, що розглядається, бо пріоритетним $є$ швидкість росту, довжина тулуба і прижиттєва товщина шпику, тобто бонітувальні на даний час ознаки продуктивності свиней.

Аналіз ефективності відтворення стада при розведенні “в собі” генотипів української м'ясної породи Харківської і Дніпропетровської селекції, де основним методом $€$ природне парування, встановлено, що із 198 свиноматок цих генотипів, спарованих за першим разом, опоросилося 163 голови, тобто ефрективність відтворення склала 82,3\%, що на 9,4\% вище, ніж при штучному осіменінні, але різниця була невірогідна $(P<0,05)$. Ефективність запліднення повновікових свиноматок, даних генотипів склала 75,7\%, ремонтних свинок - 90,8\%. Порівнюючи ефрективність методів запліднення (штучне і природне) i, враховуючи вік тварин (повновікові або ремонтні свинки), треба зазначити, що в наших дослідах запліднюваність повновікових свиноматок

при різних методах розведення була на $3,6 \%$ вищою при штучному осіменінні, ніж при природному паруванні тварин (досліди №l - III, VI, VII). В той же час, в групі ремонтних свинок ефективність штучного осіменіння становила $58,1 \%$ проти 90,8\% після природного парування. Отже метод відтворення в системі розведення суттєво не впливає на ефективність запліднення ремонтних свинок, в той же час, цей показник більше залежить від рівня племінної роботи із поголів'ям свиноматок, у напрямку удосконалення відтворювальної здатності за цією ознакою [2,3, 9-11].

Висновки. 1. Ефективність використання племінних плідників обумовлюється не тільки племінними якостями, але й кількістю і якістю одержаної від них сперми.

2. Оцінка плідників і добір їх за репродуктивною функцією сприяє формуванню у стаді фактору селекційного забезпечення ефективного відтворення поголів'я.

3. Біохімічний аналіз сперми кнурів, на нашу думку, може мати такий же статус для визначення стану здоров'я i породної приналежності як і біохімічний склад крові.

\section{Список використаної літератури:}

1. Зєльдін В. Ф. Якість сперми кнурів-плідників. Ferma №1, 2019 с.140-141

2. Зельдін В. Ф. Формування генеалогічно обумовленого рівня продуктивності свиней. Теорія і практика розвитку вівчарства України в умовах євроінтеграції: 4-а міжнародна наукова конференція. Дніпро, 2019. С. 155

3. Зєльдін В. Ф. Спосіб оцінки репродуктивної якості кнурів. Зернові культури. Бюлетень Дніпро. Інститут зернових культур. 2019 №1, С. 159-162

4. Зельдин В .Ф. Взаимосвязь показателей качества сперми хряков разных генотипов с продуктивностью свиноматок и потомков. Научное обеспечение развития животноводства в Российской федерации: Международная научнопрактическая конференция, посвященная 90-летию академика Л .К. Эрнста. ФГБНЦ ФНЦ ВИЖ им. Л.К. Эрнста. Дубровицы, 2019. C.184-187 
5.Инструкция по организации и технологии работы станций и предприятий по искусственному осеменению сельскохозяйственных животных, МСХ СССР, 1981

6. Інструкція з бонітування свиней. - К.: Видавничо-поліграфрічний центр. «Київський університет», 2003.-64 с.

7. Коваленко В. Ф. Підвищення репродуктивної здатності свиней. Київ: Урожай, 1985. 96 с.

8. Курило Ю. Г., Иванищенко Г. Е. Физиологические и биохимические аспекты искусственного осеменения и воспроизводства свиней. Повышение эфффективности свиноводства. - М.: Агропромиздат, 1991. - С.161.

9. Медведев В. А и др. Методические рекомендации по оценке хряков в условиях промышленных комплексов. - Харьков, 1978. - С. 3. Бюл.№15

10. Патент №136193 «Спосіб оцінки репродуктивної здатності свиноматки» заявл. 18.02.2019; опубл.12.08.2019,

11. Пелих В. Г. Селекційні методи підвищення продуктивності свиней: монографрія. Херсон: Атлант, 2002. 263 с.

12. Плохинский Н. А. Руководство по биометрии для зоотехников. М. Колос. С. 56-90

13. Почерняев Ф. К. Технология племенного свиноводства. - К.: Урожай, 1982. С. 3-5.

14. Смирнов В. Реализация воспроизводительного и адаптивного потенциала свиноматок при ухудшении среды на комплексе. Зоотехния. - 2001. № 6. С. 22-25. C.22-24

15. Степанов В., Михайлов Н., Костылев Э. Оценка воспроизводительных качеств свиней Зоотехния.2001. №12.

16. Халак В. И., Бордун А. Н., Зельдин В. Ф., Ильченко М. А. Показатели собственной продуктивности ремонтных свинок и воспроизводительные качества свиноматок разной племенной ценности. Наука и образование в современном мире. Вызовы XXI века: III международная научно-практическая конференция 2019. С. 388

\section{References:}

1. Zel'din V. F. 2019. Yakist' spermy knuriv-plidnykiv [Sperm quality of breeding boars] Ferma. №1, p.140-141

2. Zel'din V. F. 2019. Formuvannya henealohichno obumovlenoho rivnya produktyvnosti svyney.[Formation of genealogically determined level of pig productivity]. Theory and Practice of Sheep Development of Ukraine in the context of European integration. Materialy 4-yi mizhnarodnoyi naukovoyi konferentsiyi. Dnipro. p. 155

3. Zel'din V. F. 2019. Sposib otsinky reproduktyvnoyi yakosti knuriv [A method of assessing the reproductive quality of boars]. Dnipro. Grain crops. №1, Institute of Cereals. p. 159-162

4. Zel'din V. F. 2019. Vzaimosvyaz' pokazateley kachestva spermi khryakov raznykh genotipov s produktivnost'yu svinomatok i potomkov. [The relationship between the quality indicators of semen of boars of different genotypes with the productivity of sows and offspring]. Nauchnoye obespecheniye razvitiya zhivotnovodstva v Rossiyskoy federatsii: Materialy Mezhdunarodnoy nauchno-prakticheskoy konferentsii, posvyashchennoy 90-letiyu akademíka L.K. Ernsta. Dubrovitsy. p.184-187

5. Instruktsiya po organizatsii i tekhnologii raboty stantsiy i predpriyatiy po iskusstvennomu osemeneniyu sel'skokhozyaystvennykh zhivotnykh. 1981. [Instructions on the organization and technology of work of stations and enterprises for artificial insemination of farm animals]. MSKH SSSR

6. Instruktsiya z bonituvannya svyney. 2003. [Instructions for grading pigs] - K.: Vydavnycho-polihrafichnyy tsentr. Kyyivs'kyy universytet. $64 \mathrm{p}$.

7. Kovalenko V. F. 1985. Pidvyshchennya reproduktyvnoyi zdatnosti svyney. [Improving the reproductive capacity of pigs]. K.: Urozhay. 96 p.

8. Kurilo Yu. G., Ivanishchenko G. Ye. Fiziologicheskiye i biokhimicheskiye aspekty iskusstvennogo osemeneniya i vosproizvodstva sviney. [Physiological and biochemical aspects of artificial insemination and reproduction of pigs]. Povysheniye effektivnosti svinovodstva. - M.: Agropromizdat, 1991. p. 161.

9. Medvedev V. A i dr. 1978. Metodicheskiye rekomendatsii po otsenke khryakov v usloviyakh promyshlennykh kompleksov. [Guidelines for assessing boars in industrial complexes]. Khar'kov, p. 3.

10. Patent №136193 «Sposib otsinky reproduktyvnoyi zdatnosti svynomatky. [Method for assessing the reproductive capacity of sows]. zayavl. 18.02.2019; opubl.12.08.2019, Byul. №15

11. Pelykh V. H. Selektsiyni metody pidvyshchennya produktyvnosti svyney. [Selection methods to increase the productivity of pigs: a monograph]. Kherson: Atlant, 2002.- 263 p.

90

12. Plokhinskiy N.A. Rukovodstvo po biometrii dlya zootekhnikov. [A guide to biometrics for zootechnicians]. M. Kolos. p. 56-

13. Pochernyayev F. K. 1982. Tekhnologiya plemennogo svinovodstva. [Pig breeding technology]. K. Urozhay. p. 3-5.

14. Smirnov V. Realizatsiya vosproizvoditel'nogo i adaptivnogo potentsiala svinomatok pri ukhudshenii sredy na komplekse. 2001. [Realization of reproductive and adaptive potential of sows with deterioration of the environment on the complex]. Zootekhniya. № 6. p. 22-25.

15. Stepanov V., Mikhaylov N., Kostylev E. 2001. Otsenka vosproizvoditel'nykh kachestv sviney [Evaluation of the reproductive qualities of pigs]. Zootekhniya. №12. p. 22-24

16. Khalak V. I., Bordun A. N., Zel'din V. F., Il'chenko M. A. 2019. Pokazateli sobstvennoy produktivnosti remontnykh svinok i vosproizvoditel'nyye kachestva svinomatok raznoy plemennoy tsennosti. [Indicators of own productivity of gilts and reproductive qualities of sows of different breeding values]. Nauka i obrazovaniye v sovremennom mire. Vyzovy XXI veka III Mezhdunarodnaya nauchno-prakticheskaya konferentsiya. p. 388 
Zeldin Valeriy Felixovych, PhD of Agricultural Sciences,

Kozyr Volodymyr Semenovych, Doctor of Agricultural Sciences, Academician of NAAS of Ukraine

Sokrut Olexandr Volodymyrovych, PhD of Agricultural Sciences,

SI Institute of Grain Crops NAAS (Dnipro, Ukraine)

Monitoring of blood condition and sperm quality of breeding boars of different genotypes and efficiency of reproduction of the herd

The biochemical composition of blood and semen of breeding boars of breeding enterprises of large white breed, Ukrainian meat, Kharkiv and Dnipropetrovsk selection was studied. Establishments that the average biochemical parameters of blood and semen of boars did not exceed the biological norm. The average number of sperm in the filtered boar ejaculate of the experimental genotypes was in the range of 42.441-54.648 billion, with an ejaculate size of 202.0 $\pm 6.3-248.4 \pm 10.2 \mathrm{ml}$ and a concentration of sperm moving in a straight line gradually $0.21 \pm 0.003-0.23 \pm 0.01$ billion Jr. There is a highly probable difference in the volume of filtered ejaculate between the offspring of the Ukrainian meat breed of Dnipropetrovsk and Kharkiv selections in favor of the former. The correlation coefficient between the $\mathrm{pH}$ of boar sperm of experimental genotypes and sperm concentration in $1 \mathrm{~cm}$ was -0.323 (large white breed) - 0.294 (Ukrainian meat breed of Kharkiv selection), - 0.208 (Ukrainian meat breed of Dnipropetrovsk selection). The level of representativeness of the calculated correlation coefficients between traits was in the range of $P>0.05-P<0.05$. The average number of semen doses obtained from one ejaculate was 8.5 doses (meat breed of Kharkiv selection) and 10.9 doses of Ukrainian meat breed of Dnipropetrovsk selection (at the rate of 10.0 doses in boars of large white breed). Fertilization of uterine livestock from the first insemination, depending on the method of breeding was in the range of $62.5-83.1 \%$ at the level of reproductive capacity of sows $8.7 \pm 0.18-11.7 \pm 0.25$ piglets per farrowing, which generally characterizes the quality of the uterine population in the ability to fertilize during one sexual cycle and the level of breeding in the herd direction of improvement of a trait with a low degree of its inheritance.

Key words: genotype, blood, semen, breeding boar, reproduction efficiency

Дата надходження до редакції: 17.11.2020 р. 